\title{
Johtamisen ja työskentelyn uutta ajattelutapaa etsimässä
}

\author{
Marja Mäkipeska ja \\ Terttu Niemelä (1999) \\ Hengittävä työyhteisö \\ - johtamista muutos- \\ virrassa. \\ EDITA.
}

\begin{abstract}
Mäkipeska ja Niemelä ovat tarttuneet lehdistössäkin paljon viime aikoina keskusteltuun työuupumuksen teemaan. He eivät kuitenkaan ole tyytyneet vain toteamaan, millaiset seikat aiheuttavat työuupumusta ja ongelmia työpaikoilla, vaan ovat myös pyrkineet kehittämään uudenlaista ajattelutapaa johtamiseen ja työskentelyyn.
\end{abstract}

\section{Kirja alkaa työyhteisön} nykytilan kartoituksella. Heti alussa todetaan muutoksen välttämättömyys. Tekijät toteavat työyhteisöissä vallitsevan "ymmällään olon kaiken väsymyksen ja harmauden edessä.” Alussa myös sälytetään suurin vastuu työyhteisöjen kehittämisestä esimiehille, joiden tulisi välittää ihmisistä ja toimia rehellisesti ja suorasti alaisiaan kohtaan palautteenannossa ja suhteessa myös itseensä. Tekijät määrittelevät tarkoittavansa työyhteisön hengittävyydellä "tervettä, vuorovaikutteista ja käytännönläheistä yhteyttä ympäristöön ja ihmisiin."

\section{Tekijät kuuluttavat}

ajattelumallien muuttamisen tarvetta. He näkevät nykyisten työyhteisöjen olevan liian mekanistisia ja edelleen liiaksi tayloritisesti organisoituja. Tekijät kokevat myös johtamisen olevan edelleen liialti autoritaarista huolimatta siitä, että esimiehet usein itse kokevat johtavansa uudenaikaisesti valmentaen ja vuorovaikutteisesti valtuuttaen.

\section{Ohjeeksi vallitsevan} tilan muuttamiseen tekijät suosittelevat organisoitumista ihmisten ehdoilla. Tämä merkitsisi ihmisten henkisen kapasiteetin entistä parempaa hyväksymistä ja työtehtävien laajentamista sekä rikastamista yksilöiden kapasiteetin mukaisesti. Tekijät korostavat sitä, ettei ihminen ole kustannustekijä, vaan potentiaalista voimavaraa, johon kannattaa panostaa. Tekijät näkevätkin tulevaisuuden haasteena organisaatioille olevan "antaa ihmisille enemmän vastuuta ja mahdollisuuksia itseohjautuvuuteen, luovuuteen ja kehittymiseen."

\section{Kirjassa kannustetaan} lukijaa omaksumaan positiivinen ihmiskäsitys, jossa korostuu ihmisen arvostaminen ja ihmisten rohkaiseminen omaaloitteellisuuteen ja luovuuteen. Esimiehiä kannustetaan siirtymään myötävirtaan johtamiseen, jolla tekijät tarkoittavat sitä, että esimies muuttaisi roolinsa yksinäisestä vastuunkantajasta auttajaksi, tukijaksi ja edellytysten luojaksi.

Kirjassa esitetyn viitekehyksen vahvuutena on sen selkeys ja helppolukuisuus.
Vaikka useimmat esitetyistä väitteistä ovat sellaisia, että niihin voi lämpimästi yhtyä, voi sittenkin kysyä, mikä kirjassa on uutta. Kirjassa esitetyn "uuden" ajattelutavan siemeniä on monissa seminaareissa ja kirjoissa toistettu jo lukuisia vuosia. Esimerkiksi muutoksen entistä vastuullisemmaksi henkilöksi tunnistin Argyrisin kirjoista jo 1970-luvun alussa. Ehkä on kuitenkin edelleen tarvetta esittää näitä uudistamisen ajatuksia.

\section{Kirjan parasta antia on} siinä esitetty yritysesimerkki W.L Gore \& Associates. Tämän yritysesimerkin opetukset ovat sellaisia, että niihin soisi mahdollisimman monen tutustuvan. Tässä yritysesimerkissä valtuuttava johtamistapa ja ihmisten voimavarojen täysipainoinen hyödyntäminen toimii tavalla, josta monet organisaatiot voisivat ottaa oppia.

\section{Tapausesimerkki}

osoittaa, kuinka humanistisille arvoille perustuva organisoituminen voi olla tietoyhteiskunnassa myös tehokas ja tuottava tapa organisoitua. Sitä paitsi saattaa olla, että tuo tapa on jatkossa lähes ainoa toimiva tapa, koska työt muuttuvat entistä tietointensiivisempään suuntaan ja organisaatioista tulee yhä useammin virtuaalisia, verkostoituneita, asiantuntijaorganisaatioita. 


\section{Kirjan loppuosa}

käsittelee johtamisen ja vuorovaikutuksen kehittämistä. Kirjan sanoma on tältä osin selkeä. Kirjassa suositellaan vuorovaikutteista johtamistapaa, joka lähtee liikkeelle ihmisten omista arvoista. Samalla suositellaan esimiehille uu- denlaisen roolin omaksumista, jossa painottuu valmentajan, osallistujan ja visioijan rooli. Kirjan suosituksia lukiessa ei voi välttyä ajatukselta, että olisi joskus aikaisemmin kuullut ja nähnyt ehkäpä jopa kirjoittanutkin samantapaisia aiheita kuin kirjassa esitetään.
Tästä huolimatta uskallan suositella kirjaa sen sisältämien ajatusten sisällön ja tuoreuden sekä kirjan selkeyden ja helppolukuisuuden vuoksi kaikille.

Pauli Juuti 